\title{
Rathke's cleft cyst
}

\author{
STEVEN P. RINGEL AND ORVILLE T. BAILEY
}

From the Department of Neurosurgery, Abraham Lincoln School of Medicine, Chicago, Illinois, U.S.A.

SUMMARY A 29 year old female with a chiasmal syndrome secondary to a Rathke's cleft cyst is described. The histology and pathogenesis of these rare cysts are discussed, contrasting them with other hypophysial cysts.

This paper describes an example of a Rathke's cleft cyst in which the patient unexpectedly died before surgery. Such cysts are of interest partly because of problems in their histogenesis and partly because of their favourable prognosis in most instances.

\section{CASE HISTORY}

A 29 year old Negro female developed bifrontal headaches occurring each morning for one year. They were poorly relieved by analgesics. Four months before admission her visual acuity gradually decreased. This progressed in severity until she was unable to see 'out of the corner of her eyes'. She complained of intermittent diplopia on primary gaze, usually a transient phenomenon.

There was no menstrual irregularity, loss of libido, changes in hair distribution or in skin texture. She had lost $5.5 \mathrm{~kg}(12 \mathrm{lb})$ over the last year. Recently she had noted progressive nocturia and some increase in thirst.

The general physical examination, including body habitus and hair distribution, was normal. Bitemporal hemianopsia was present, with an additional junctional left scotoma. Visual acuity was 20/40 on the right but the patient was able to count fingers only with the left eye. There was mild optic atrophy bilaterally on the funduscopic examination. The remainder of the neurological examination was within normal limits.

Right brachial arteriography showed posterior displacement of the basilar artery away from the clivus. Brain scan, optic foramen views, and laminograms of the sella turcica were normal. In the electroencephalogram there were a few diffuse low voltage 6/ second spike and wave discharges maximal in the parieto-occipital area. On lumbar puncture the opening pressure was $320 \mathrm{~mm}$; there were no cells and protein was $40 \mathrm{mg} / 100 \mathrm{ml}$. of CSF. Because of the elevated pressure, it was elected not to do a pneumo. encephalogram. A ventriculogram with Conray revealed a large suprasellar mass amputating and displacing the recesses of the anterior aspect of the third ventricle (Fig. 1). No ventricular enlargement was present.

Endocrine studies included plasma cortisol $1.8 \mu \mathrm{g}$ and protein bound iodine $5.2 \mu \mathrm{g} / 100 \mathrm{ml}$.; urinary ketosteroids $1.0 \mathrm{mg} / 24 \mathrm{hr}$; gonadotrophins negative at 5,50 , and $100 \mathrm{~m} \mu$; serum osmolality $304 \mathrm{~m}$-osmol/ $\mathrm{kg}$; urine osmolality $97 \mathrm{~m}-\mathrm{osmol} / \mathrm{kg}$.

Two hours after the Conray ventriculogram the patient became obtunded, developed recurrent seizures and fever. Six hours later, she suddenly died.

Gross examination of the brain (Fig. 2) revealed a $2.8 \times 2.5 \times 2.0 \mathrm{~cm}$ cyst at the base, lying just superior to the pituitary body, which was adherent to the surface. The cyst impinged on the inferior aspect of the optic chiasm and there was mild atrophy of the hypothalamus.

Microscopic examination (Figs 3 and 4) showed that the cyst emerged from the centre of a normal appearing pituitary body and projected in large part outside it. It was lined by well-defined ciliated high columnar epithelium. In some areas the epithelium had become disrupted and the wall was formed by clearly defined fibrous tissue. The cyst was filled with a colloid-like material and desquamated epithelial cells. Deeper parts of the wall of the cyst consisted of dense fibrous connective tissue and a few chronic inflammatory cells. One small loculated area contained cholesterol crystals.

\section{DISCUSSION}

Rathke's cleft cysts are usually an incidental finding at necropsy but occasionally they become large enough to produce symptoms. Goldzieher in 1913 described the first case in a 34 year old man with diabetes insipidus. Since this time 32 cases have been described, 18 of which have been removed surgically (Berry and Schlezinger, 1959; 


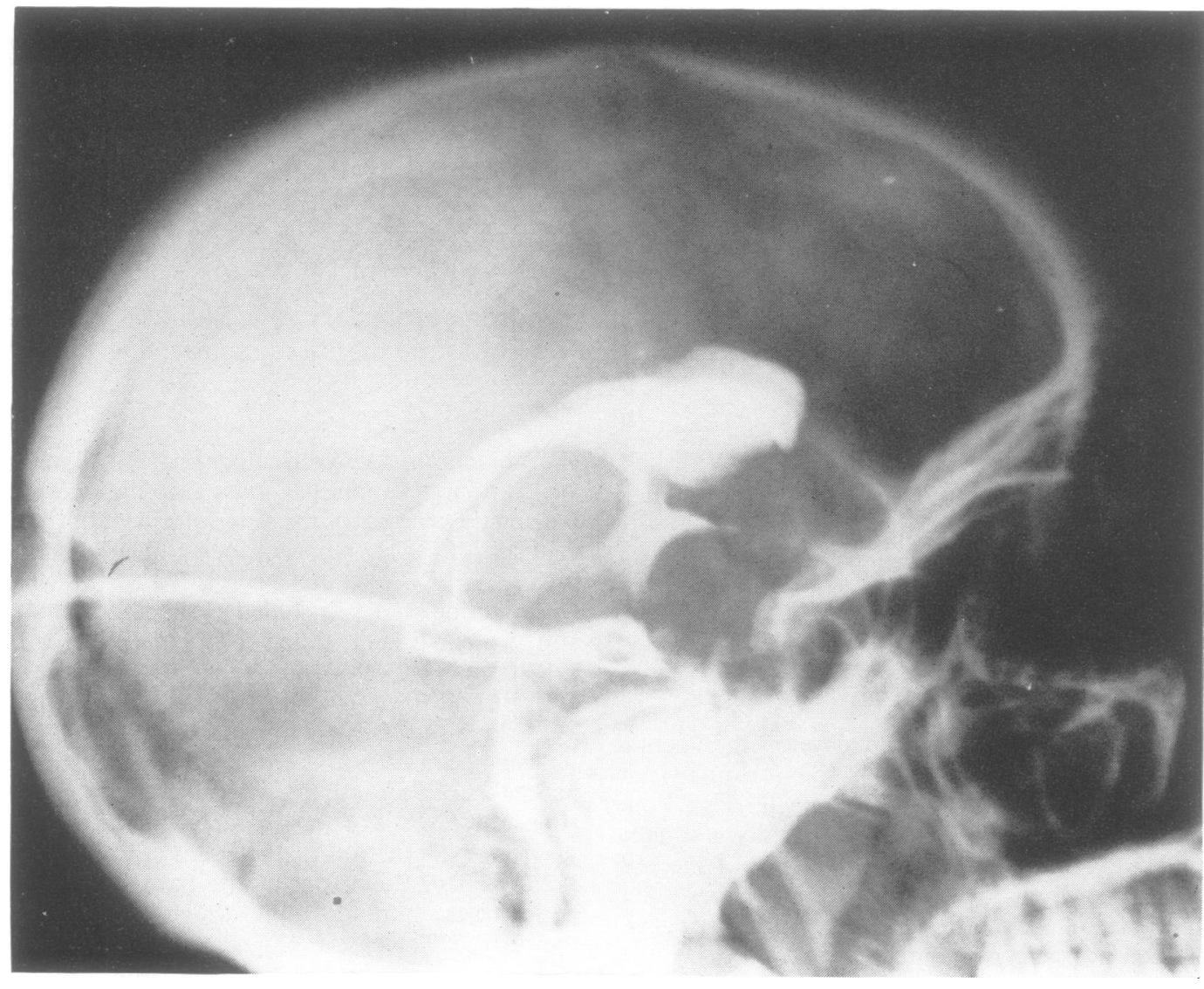

FIG. 1. Conray ventriculogram, showing amputation and displacement of anterior third ventricle.

Giuffré and Gagliardi, 1968; Shuangshoti, Netsky and Nashold, 1970). Berry and Schlezinger (1959) classified the examples into three groups: (1) those with suprasellar symptoms, such as visual impairment or hypothalamic dysfunction; (2) those with hypophysial dysfunction; and (3) those with no symptoms referable to the hypophysial region. The course of those patients in whom the cysts were removed was usually better than those with pituitary adenomas or craniopharyngiomas. Only two of the 18 patients who had surgery developed a recurrence of the cyst (Berry and Schlezinger, 1959; Rashkind, Brown, and Mathis, 1968). One patient died postoperatively (Duffy, 1920). The rest of the patients remained asymptomatic after surgery. Thus, differentiation of Rathke's cleft cysts from other lesions in this area is essential because of this difference in prognosis.

The cysts are usually confined to the sella turcica, although suprasellar extension has been $\frac{\circ}{3}$ described (Bayoumi, 1948; Naiken, Tellem, and $\supsetneq$ Heranze, 1961; Russell and Rubinstein, 1971). In two patients they were associated with pituitary adenomas (Duffy, 1920; Shuangshoti et al., 1970).

Microscopically, the epithelial lining of $a \stackrel{3}{.}$ Rathke's cleft cyst usually consists of cuboidal to columnar epithelial cells with or without cilia, often with some transition to mucin-secreting goblet cells (Berry and Schlezinger, 1959). $\frac{7}{0}$ Deeper, there is fibrous connective tissue with moderate numbers of inflammatory cells.

It is generally thought that these cysts derive $N$ 


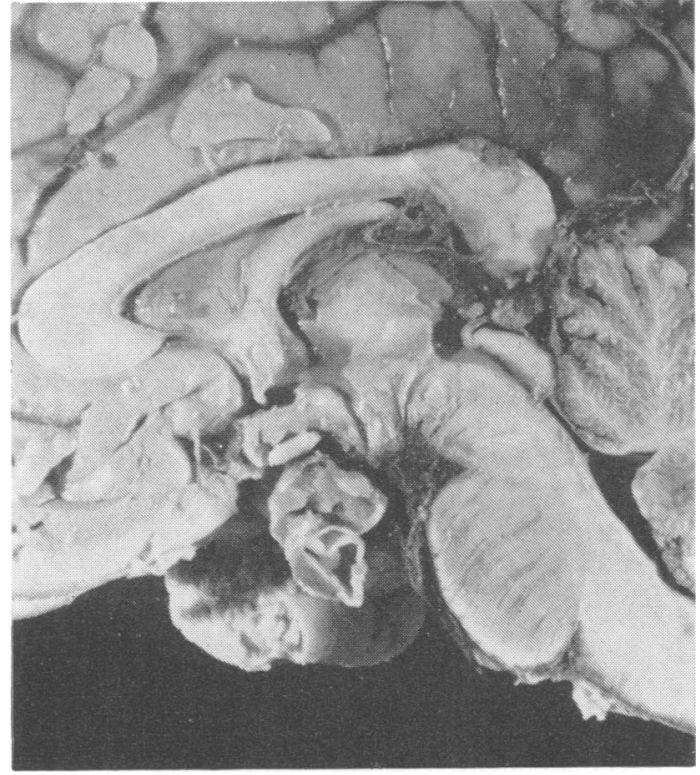

FIG. 2. Photograph of suprasellar cyst.

from Rathke's pouch during the embryological development of the pituitary gland. In the third or fourth week of gestation, the roof of the stomodeum, lined by simple ciliated columnar cells, folds intracranially anterior to the oropharyngeal membrane to form Rathke's pouch. This elongates into the thin orohypophysial or craniopharyngeal duct. By the seventh week of gestation all but the cranial part of the orohypophysial duct lumen obliterates, leaving a small cavity called the pituitary pouch and the orohypophysial stalk. At the same time, a neuroepithelial lined protrusion of the third ventricle, the infundibulum, makes contact with this pituitary pouch (Berry and Schlezinger, 1959; Innes and Saunders, 1962). The anterior wall of the pituitary pouch becomes the anterior lobe of the pituitary gland. In addition, a small portion of the anterior lobe extends to surround the infundibulum and become the pars tuberalis. The posterior wall of the pituitary pouch becomes the pars intermedia. This intermediate lobe touches the infundibulum, which in turn gives rise to the pituitary stalk and to the posterior lobe of the pituitary body. Although the pituitary pouch is usually obliterated by numerous epithelial infoldings, any residual

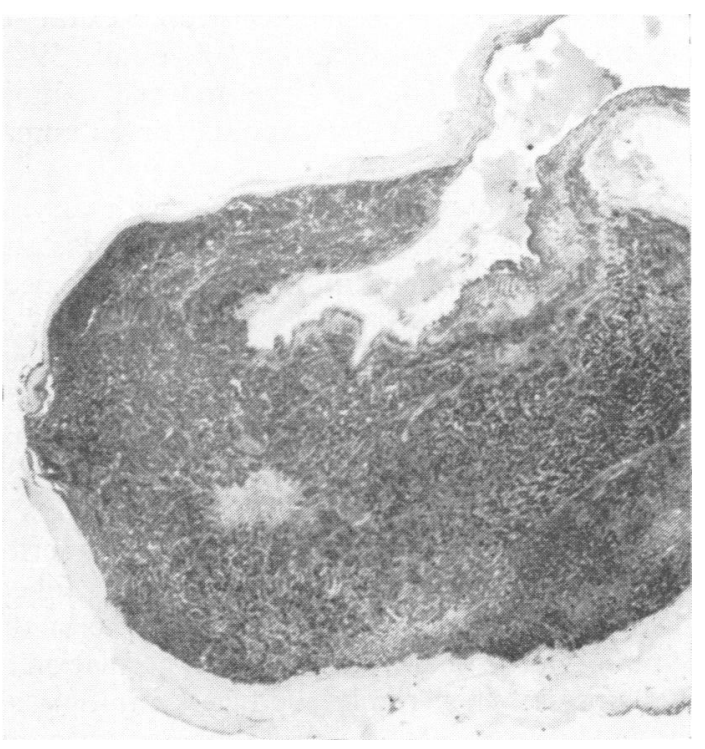

FIG. 3. Relation of suprasellar cyst to anterior lobe of pituitary gland. $H$ and $E, \times 8$.

lumen between the anterior and intermediate lobes is named Rathke's cleft or the cleft of Rathke's pouch. This cleft consists of the original stomodeal secretory epithelium which is ciliated, cuboidal, or columnar, and secretes mucin.

Dilatation of this cleft into a Rathke's cleft

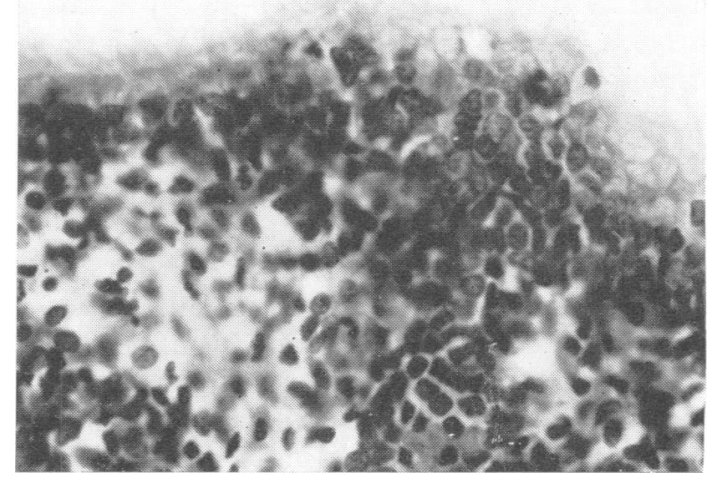

FIG. 4. Ciliated high columnar cells forming lining of suprasellar cyst. $H$ and $E, \times 375$. 
cyst occurs in $13-22 \%$ of randomly examined pituitary glands if small microscopic examples are taken into consideration (Bayoumi, 1948; Shanklin, 1949). They may be multiple, contain colloid, and be lined by cuboidal or columnar epithelium.

Similar pituitary cysts are found with varying frequencies in amphibians, reptiles, birds, and most mammals (Shanklin, 1949). They have been described in almost $100 \%$ of chickens and $10 \%$ of guinea-pigs. Malformations involving remnants of the craniopharyngeal duct are present in $70 \%$ of short-nosed dogs but in only $10 \%$ of normal or long-nosed dogs (Innes and Saunders, 1962). These duct remnants are usually present as a cystic formation in the periphery of the anterior lobe of the pituitary body and in the pars tuberalis. Frequently, they exceed the volume of the hypophysial parenchyma and cause herniation of the capsule. They rarely produce symptoms although genital atrophy and diabetes insipidus have been reported occasionally (Innes and Saunders, 1962).

Recently, Shuangshoti et al. (1970) have proposed that not all cysts originate from Rathke's pouch but that neuroepithelium may be pinched off to form ependymal-lined tubules within the pituitary gland and around the stalk. They feel that epithelial cysts related to the sella turcica are histologically and histochemically indistinguishable from neuroepithelial (colloid) cysts. This suggests that cilia, mucin, and mucopolysaccharides are not specific for the glandular epithelium of Rathke's cleft, but also are present in neuroepithelium. Some support for this view exists, since gland-like structures are also present in the posterior lobe of the pituitary body in early life (Shanklin, 1951). These tubuloracemose glands connect with the Rathke's cleft lumen. Normally they involute in the adult, leaving only the 'salivary glands of Erdheim' as residua (Berry and Schlezinger, 1959).

Furthermore, Rowbotham and Clark (1956) described a cuboidal lined cyst filled with colloid attached only to the tuber cinereum. They felt that it was derived from an ependymal prolongation of the third ventricle into the infundibulum. In four examples of Rathke's cleft cysts, tubuloracemose glands have been noted (Duffy, 1920; Messimy, Namin, and Martinès, 1955; Fager and Carter, 1966; Giuffré and Cagliardi, 1968), so that a neuroepithelial origin cannot definitely be excluded.

Rathke's cleft cysts differ sharply histologically $\stackrel{\mathbb{D}}{=}$ from the more common craniopharyngioma or o hypophysial stalk cyst (Duffy, 1920; Frazier and $\frac{c}{0}$ Alpers, 1934), the stratified squamous epithelium 0 of the craniopharyngioma contrasting with the ciliated columnar epithelium and goblet cells seen in the Rathke's cleft cysts. The development $\stackrel{0}{2}$ of craniopharyngiomas at the level of the pituitary stalk or tuber cinereum has been attributed to small nests of squamous cells commonly found at postmortem examination in the adult (Erd- 흘 heim, 1904; Luse and Kernohan, 1955) and less commonly in the newborn pituitary gland (Goldberg and Eshbaugh, 1960). These lie near the क junction of the stalk with the pars distalis, but may $\overrightarrow{0}$ also occupy the pars tuberalis (Russell and $\mathrm{Ru}-\overrightarrow{-}$ binstein, 1971). Some authors have felt that these $\stackrel{\omega}{\sigma}$ squamous cells also represent remnants of the original Rathke's cleft that have undergone squamous metaplasia. No conclusive evidence has been found to indicate that the craniopharyn or gioma represents an outgrowth of Rathke's clefof 6 However, transitions have been found from the flat, cuboidal, or columnar cells lining the Rathke's cleft cysts (Fulstow, 1928; Frazier and Alpers, 1934). Russell and Rubinstein (1971) reg 웅 port two cases of dumb-bell tumours in whici the intrasellar portion was lined by a singes. layer of ciliated epithelium, while the supra sellar part consisted of squamous epithelium. The transition of epithelium occurred abruptly at the level of the diaphragma sellae.

\section{REFERENCES}

Bayoumi, M. L. (1948). Rathke's cleft and its cysts. Edinburgh Medical Journal, 55, 745-749.

Berry, R. G., and Schlezinger, N. S. (1959). Rathke-cleft cysts. Archives of Neurology, 1, 648-58.

Duffy, W. C. (1920). Hypophyseal duct tumors. A report of three cases and a fourth case of cyst of Rathke's pouch Annals of Surgery, 72, 537-555, 725-757.

Erdheim, J. (1904). Über Hypophysenganggeschwülste und Hirncholesteatome. Sitzungsberichte der Kaiserlichen Akademie der Wissenshaften in Wien, 113, abt 3, 537-726.

Fager, C. A., and Carter, H. (1966). Intrasellar epithelial cysts. Journal of Neurosurgery, 24, 77-81.

Frazier, C. H., and Alpers, B. J. (1934). Tumors of Rathke's cleft (hitherto called tumors of Rathke's pouch). Archives of Neurology and Psychiatry, 32, 973-984.

Fulstow, M. (1928). An epithelial cyst of the hypophysis American Journal of Pathology, 4, 87-90.

Giuffré, R., and Gagliardi, F. M. (1968). Unusual hypophyseal tumour of Rathke's cleft origin. Neurochirurgia, 11. 81-89.

年


Goldberg, G. M., and Eshbaugh, D. E. (1960). Squamous cell nests of the pituitary gland as related to the origin of craniopharyngiomas. Archives of Pathology, 70, 293-299.

Goldzieher, M. (1913). Über Sektionsbefunde bei Diabetes insipidus. Verhandlungen der Deutschen Pathologischen Gesellschaft, 16, 281-287.

Innes, J. R. M., and Saunders, L. Z. (1962). Comparative Neuropathology. Academic Press : New York.

Luse, S. A., and Kernohan, J. W. (1955). Squamous-cell nests of the pituitary gland. Cancer, 8, 623-628.

Messimy, R., Namin, P., and Martinès, N. (1955). Tumeur kystique de l'hypophyse de type vésiculaire, à revêtement cilié. Troubles pigmentaires associés. Revue Neurologique, 92, 235-240.

Naiken, V. S., Tellem, M., and Meranze, D. R. (1961). Pituitary cyst of Rathke's cleft origin with hypopituitarism. Journal of Neurosurgery, 18, 703-708.
Raskind, R., Brown, H. A., and Mathis, J. (1968). Recurrent cyst of the pituitary: 26-year follow-up from first decompression. Case report. Journal of Neurosurgery, 28, 595-599.

Rowbotham, G. F., and Clarke, P. R. R. (1956). Colloid cyst of the pituitary gland causing chiasmal compression. British Journal of Surgery, 44, 107-108.

Russell, D. S., and Rubinstein, L. J. (1971). The Pathology of Tumours of the Nervous System, 3rd edn. Arnold: London. Shanklin, W. M. (1949). On the presence of cysts in the human pituitary. Anatomical Record, 104, 379-407.

Shanklin, W. M. (1951). The incidence and distribution of cilia in the human pituitary with a description of microfollicular cysts derived from Rathke's cleft Acta Anatomica, 11, 361-382.

Shuangshoti, S., Netsky, M. G., and Nashold, B. S. Jr. (1970). Epithelial cysts related to sella turcica: proposed origin from neuroepithelium. Archives of Pathology, 90, 444-450. 